\title{
Redactioneel
}

\section{Olympische Spelen onder het vergrootglas}

\author{
Rein Halbersma*
}

De Olympische Winterspelen in PyeongChang zijn inmiddels afgelopen als dit nummer bij u als lezer op de mat is beland. Bij het ter perse gaan van dit nummer stond de openingsceremonie op het punt te beginnen. Daarbij hebben zich op voorhand donkere wolken samengepakt boven het Olympische vuur: zowel de nucleaire dreiging tussen Noord-Korea en de Verenigde Staten als de grootschalige dopingmaatregelen tegen Russische atleten.

Nu heeft de Olympische beweging al de nodige geopolitieke stormen (zoals staatspropaganda, aanslagen en boycots) doorstaan. En alhoewel nalevingstoezicht op internationale (militaire) verdragen op zichzelf een interessant thema is, ${ }^{1}$ ligt de focus van dit nummer op toezicht en sport. Ik laat het daarom bij de hoopvolle constatering dat de noorderbuur van het gastland - net als destijds het krijgszuchtige Sparta - een Olympische vrede in acht lijkt te gaan nemen.

Vanuit juridisch perspectief is de sterk door sportbonden ingeperkte ruimte voor commerciële en politieke expressie van individuele sporters een actueel en relevant thema. De ruimte voor commerciële uitingen onder de betwiste IOC-regel 40 komt an bod in de rubriek 'Notenkraker'. ${ }^{2}$ De bekendste voorbeelden van politieke uitingen vonden plaats in 1968, toen verschillende medaillewinnaars bij hun huldiging het waagden te protesteren tegen geopolitiek of maatschappelijk onrecht: de Tsjechoslowaakse turnster Věra Ćáslavská tegen de Sovjetinval in haar land eerder dat jaar; de Amerikaanse

Dr. R.S. Halbersma is onderzoekscoördinator bij de Kansspelautoriteit.

1. O. Avdeyeva, 'When do states comply with international treaties? Policies on violence against women in post-communist countries', International Studies Quarterly 2007, 51(4), p. 877-900.

2. De uitsluiting als gevolg van onacceptabel uitgaansgedrag van turner Yuri van Gelder in Rio 2016 illustreert weliswaar de zwakke rechtspositie van individuele sporters, maar valt moeilijk aan te merken als een inperking van de ruimte voor commerciële of politieke expressie. atleten Tommie Smith en John Carlos tegen de achterstelling van zwarte burgers in hun land. Een vergelijkbaar maatschappelijke protest vindt momenteel plaats in de Verenigde Staten door het knielen van American Footballspelers tijdens het spelen van het volkslied als protest tegen politiegeweld tegen minderheden.

De hierboven genoemde Amerikaanse atleten werden destijds uitgesloten van de Olympische Spelen, en hun loopbaan is daardoor als een nachtkaars uitgegaan. American Football-quarterback Colin Kaepernick betaalt momenteel eenzelfde hoge prijs voor het initiëren van het knielen, nadat zijn aflopende contract niet is verlengd en geen enkele andere club hem heeft willen contracteren. Het onderliggende maatschappelijke probleem van buitensporig en discriminerend politiegeweld en het toezicht daarop via technologische maatregelen als lichaamscamera's (en de openbaarheid van zulke opnamen) is een actueel en relevant onderwerp binnen de criminologie. ${ }^{3}$

Mogelijke protesten door landen en atleten daargelaten liggen de Olympische Spelen met name onder het vergrootglas vanwege de - weliswaar grootschalige maar voor velen onvoldoende vergaande - dopingmaatregelen tegen Russische atleten. De in het tweedelige McLarenrapport opgetekende conclusies liegen er niet om en bevestigen eerdere berichten van de Duitse zender ARD en de publicaties in de Amerikaanse media., ${ }^{4,5}$ Tijdens de Olympische Winterspelen 2014 in Sotsji hebben de Russische autoriteiten naar alle waarschijnlijkheid op grote schaal dopingstalen van Russische atleten verdonkermaand en verwisseld met vooraf geprepareerde

3. D.A. Harris, 'Picture this: Body-worn video devices (heads cams) as tools for ensuring fourth amendment compliance by police', Tex. Tech L. Rev. 2010, 43, p. 357.

4. McLaren Independent Investigation Report into Sochi Allegations - Part I. World Anti-Doping Agency, 18 juli 2016.

5. McLaren Independent Investigation Report into Sochi Allegations - Part II. World Anti-Doping Agency, 9 december 2016. 
'schone' monsters. Hierdoor werd de pakkans bij dopinggebruik tot nul gereduceerd.

Het eerste deel van het McLaren-rapport kwam uit vlak voor de Olympische Zomerspelen 2016 in Rio de Janeiro en betrof met name de omvang van de fraude in Sotsji 2014. Het Internationaal Olympisch Comité liet eventuele sancties over aan individuele sportbonden. Alleen de internationale atletiek- en de gewichthefbonden durfden het aan om de voltallige Russische afvaardiging te schorsen. Het IOC heeft hierop stevige kritiek gekregen, met name dat zij de commerciële belangen van een invloedrijk sportland als Rusland (o.a. organisator van het aankomende WK voetbal in 2018) liet prevaleren boven het belang van een schone sport. Het tweede deel van het McLaren-rapport, dat eind 2016 uitkwam, schetste een onthutsend beeld van systematisch dopinggebruik en -verhulling binnen de gehele Russische sport over een veel langere periode.

Het IOC heeft hierop eind 2017 via de commissieOswald vérstrekkende maatregelen genomen. De gehele Russische federatie werd als land uitgesloten van de komende Olympische Winterspelen. Bovendien werden 43 atleten (onder wie veel medaillewinnaars) van wie het McLaren-rapport aangaf dat hun dopingstalen gemanipuleerd waren, uit de uitslag van Sotsji 2014 geschrapt, en voor het leven uitgesloten van verdere Olympische deelname. Individuele Russische atleten die zelf konden bewijzen in hun hele loopbaan tot nu toe op geen enkele wijze met doping in aanraking te zijn gekomen, konden als privilege en op uitnodiging van het IOC onder de Olympische vlag meedoen. In totaal betrof het 169 atleten van wie het merendeel niet aan Sotsji 2014 had deelgenomen. Voor de Nederlandse schaatsliefhebber bekende namen als Koelizjnikov en Yuskov zaten hier niet bij op grond van eerdere uitgezeten dopingschorsingen.

Juridisch gezien is er hierdoor sprake van een omkering van de bewijslast. De commissie-Oswald van het IOC geeft zelfs onomwonden toe de onschuldpresumptie te laten varen en voor alle Russische atleten uit te gaan van een weerlegbaar rechtsvermoeden van dopinggebruik. De commissie rechtvaardigt dit door de stelselmatige en van overheidswege georkestreerde manipulatie van de integriteit van de dopingcontroles. Dat de omgekeerde bewijslast ook wel 'duivelsbewijs' wordt genoemd, geeft aan voor welk duivels dilemma het IOC zich gesteld voelde. Uitzonderlijke maatregelen in uitzonderlijke tijden dus.

Deze maatregelen hebben in ieder geval een tombola aan rechtszaken bij het internationale sporttribunaal (CAS) tot gevolg gehad in de aanloop naar de Spelen. Het CAS vond het bewijsmateriaal van het IOC onvoldoende overtuigend, draaide voor 28 van de 43 sporters de IOCschorsing en verwijdering uit de uitslag van Sotsji 2014 in zijn geheel terug en verminderde voor 11 andere atleten de levenslange uitsluiting tot enkel de uitsluiting van deelname aan de Winterspelen van 2018. Dit heeft echter niet geleid dat de gerehabiliteerde sporters alsnog door het IOC zijn toegelaten. Ook hiertegen is op het allerlaatste moment nog bij het CAS beroep aangete- kend, maar deze bezwaren zijn alle niet-ontvankelijk verklaard.

Pikant hierbij is dat de verschillende toezichthoudende instanties op onderdelen onderling sterk verdeeld lijken. Vond het CAS dat het IOC te ver ging in een aantal van zijn maatregelen, de atletencommissie van de WorldAnti-Doping-Agency (WADA) stelde juist dat het IOC niet ver genoeg ging en had het liefst een volledige uitsluiting van alle Russische atleten gezien.

Wat de langetermijngevolgen zullen zijn voor de integriteit van de (Olympische) sport in het algemeen en antidopingcontrole in het bijzonder, is moeilijk in te schatten. Vast staat dat toezichthouders machteloos kunnen komen te staan tegenover manipulatie met inzet van geavanceerde technologische middelen (zo werden verzegelde dopingmonsters geopend zonder voor het blote oog sporen achter te laten). Andere pregnante voorbeelden hiervan zijn de grootschalige fraude rondom emissiestandaarden in de auto-industrie ('sjoemelsoftware') en de recent ontdekte wijdverspreide manipulatie van de registratie van melkkoeien in Nederland.

Het voorliggende nummer is zoals eerder opgemerkt in zijn geheel gewijd aan het thema 'Toezicht en Sport'. Het is een gevarieerd nummer geworden met bijdragen vanuit verschillende invalshoeken. Daarnaast wil ik nogmaals de lezer oproepen gehoor te geven aan de call for papers voor een aankomend themanummer over toezicht rondom Big Data.

In een artikel 'Uit het veld' van Thom de Jong en Margot Aelen wordt ingegaan op de vraag hoe De Nederlandsche Bank indirect toezicht houdt op integriteitsschendingen in de voetbalsector. Sinds het Bosmanarrest midden jaren negentig is de omvang van de voetbalmarkt explosief gestegen (een onderwerp dat ook in het interview met Kesler aan bod komt), met navenante gevolgen voor toezichtrisico's. De auteurs gaan in op fenomenen als de ondoorzichtige transfermarkt, de aankoop van clubs door buitenlandse investeerders, de integriteit van bonden en bestuurders, de spelers als merk, en hoe deze scenario's een risico voor de integriteit van financiële markten kunnen vormen. Het onderzoek mondt uit in aanbevelingen voor financiële instellingen om cliënten in de voetbalsport te onderscheiden, de monitoring van transactie te verscherpen en om extra aandacht te schenken aan de transacties van bestuurders van bonden.

De hoofdmoot van dit nummer wordt gevormd door een uitgebreid interview dat de redactie hield met Henk Kesler, momenteel plaatsvervangend voorzitter van de Kansspelautoriteit, arbiter bij het CAS en voormalig directeur betaald voetbal bij de KNVB. In het interview wordt teruggeblikt op de gestage professionalisering in de afgelopen decennia van zowel de wereld van het toezicht als die van de sport. Ook komen aan bod de maatschappelijke impact van sport, zowel op de openbare orde als op de (decentrale) overheidsfinanciën, en de invloed van de groter geworden belangen bij de contractuele geschillen tussen bonden, clubs, sporters en andere betrokkenen. Tot slot komt als actueel thema de brede toezichtaanpak van matchfixing ter sprake. Hierbij 
worden momenteel op verschillende niveaus door diverse toezichthouders en stakeholders (het Functioneel parket, de politie, de Belastingdienst, de FIOD, de Kansspelautoriteit en de Doelgroep Sport) de handen ineengeslagen.

Een belangrijke doelstelling van Tijdschrift voor Toezicht is om een brug te slaan tussen wetenschap en praktijk en te faciliteren dat uiteenlopende disciplines van elkaar kunnen leren. Het essay van Bert Wagendorp (columnist van de Volkskrant) is een historisch-filosofische beschouwing over het thema 'vals spel' in de sport. Veel van de onderwerpen uit het interview met Kesler komen terug: de commercialisering, de intense media-aandacht en het verlangen van de consument naar al maar betere prestaties. Dit alles verklaart dat verschillende actoren rondom sportwedstrijden geen belang hebben om de vuile was buiten te hangen. De uitdaging voor toezicht ligt erin om zowel de entertainmentwaarde als de geloofwaardigheid van de sport in balans te houden.

In de rubriek "Opinie" komen in dit nummer twee bijdragen aan bod. Bart van der Sloot (Tilburg University) geeft een samenvatting van een mede door hem in opdracht van de Europese Commissie uitgevoerd onderzoek hoe de anti-dopingmaatregelen in sportverband zich verhouden tot het recht op privacy en gegevensbescherming. Hij betoogt op grond van zijn onderzoek dat dopingautoriteiten zichzelf te vergaande bevoegdheden aanmeten, over gebruik van middelen waarvan de werking soms twijfelachtig is, met een onevenredige impact op de privacy van sporters. Aan de juridische trits van noodzakelijkheid, proportionaliteit en subsidiariteit om is volgens zijn onderzoek niet voldaan.

Als tegengeluid betoogt Herman Ram (Dopingautoriteit) dat juist de sporters een belang hebben bij een dopingvrije sport, en dat zonder controles een dopingverbod niet effectief is. Dit resulteert in een oproep aan de wetgever om in Europees verband een wettelijke grondslag voor dopingcontroles te creëren in lijn met de Algemene verordening gegevensbescherming.

In de 'Notenkraker' gaat Vincent Geeraets (Vrije Universiteit) in op recente jurisprudentie rondom de rechtspositie van sporters. Zijn eerste constatering is dat zowel de organisatie van sporten door bonden en comités (IOC), het antidopingtoezicht (WADA) als de sportrechtspraak (CAS) zijn belegd in monopolistische entiteiten. Sporters kunnen daardoor in de praktijk bij geschillen geen kant uit, want zowel schorsingen als langlopende juridische procedures zijn vanwege hun korte loopbaan bijzonder kostbaar. Dit geeft bonden en dopingautoriteiten de mogelijkheid om vergaande beperkingen aan sporters op te leggen. Behalve op de privacybeperkingen bij dopingcontroles gaat Geeraets in op de casus Pechstein die uiteindelijk door de hoogste Duitse rechter is terugverwezen naar WADA en CAS om haar zaak te bepleiten, en op de IOC-regel 40 waarin commerciële uitingen van sporters op sociale media verregaand worden beperkt. Geeraets concludeert dat bonden en dopingautoriteiten hun doelen ook kunnen realiseren als de rechtspositie van sporters zou worden verbeterd. Tot slot signaleert hij recente kantelingen in de jurisprudentie, zoals de recente uitspraak van de Europese Commissie tegen de machtspositie van sportbonden om alternatieve wedstrijden als de Ice-Derby te verhinderen. 